\title{
Effect of advanced glycation endproducts on the secretion of insulin-like growth factor-I and its binding proteins: role in osteoblast development
}

Received: 15 September 2000 / Accepted in revised form: 23 August 2001

\begin{abstract}
In chronically uncompensated diabetes mellitus, an increase has been observed in the content of advanced glycation endproduct (AGE)-modified proteins in various tissues, including bone. This increase can lead to a local imbalance in the secretion of cytokines and growth factors, and has been implicated in the pathophysiology of the longterm complications of diabetes. We have previously shown that the proliferation and differentiation of UMR106 rat osteosarcoma and MC3T3E1 mouse calvaria-derived cell lines are regulated by AGE-modified proteins, possibly through the recognition of these AGEs by specific membrane-associated receptors. In the present study, we investigated the effects of AGE-proteins on the secretion of insulin-like growth factor-I (IGF-I) and its binding proteins (IGFBPs) by both osteoblast-like cell lines. In the case of MC3T3E1 cells, this was studied throughout their successive stages of development: proliferation, differentiation and mineralisation. For every condition, cells were incubated 24
\end{abstract}

\footnotetext{
A.D. McCarthy • S.B. Etcheverry • A.M. Cortizo $(\bowtie)$

Department of Pathological Biochemistry

Facultad de Cencias Exactas

Universidad Nacional de la Plata

Calle 47 y 115, 1900 La Plata, Argentina
}

hours with increasing concentrations of either bovine serum albumin (BSA) or AGE-BSA. IGF-I in conditioned media was separated from IGFBPs by acid gel filtration-centrifugation, and measured by radioimmunoassay. IGFBPs in conditioned media were analysed by a semi-quantitative western ligand blot. In UMR106 cells, low doses of AGEBSA significantly decreased the secretion of both IGF-I (56\% of control) and a $24 \mathrm{kDa}$ IGFBP (80\% of control). Results for MC3T3E1 cells, which predominantly secrete 29 kDa IGFBPs, were dependent on the stage of development. In proliferating preosteoblastic cells, AGE-BSA decreased the secretion of IGF-I (34\%-37\% of control) while increasing the secretion of IGFBP (124\%-127\% of control). On the other hand, secretion of these components of the IGF system by mature (differentiated) cells was unaffected by the presence of AGE-BSA. When these cells finally attained mineralisation, incubation with AGE-modified BSA provoked an increase both in IGFBP $(131 \%-169 \%$ of control) and in IGF-I secretion (119\%-123\% of control). The presented evidence suggests that the modulation of growth and development by AGE-modified proteins, previously described for both cell lines, could be the result of an autocrine-paracrine mechanism involving the IGF-IGFBP system.

Key words Diabetes mellitus - Advanced glycation endproducts $\cdot$ Bone $\cdot$ Insulin-like growth factor-I $\cdot$ Osteoblast

\section{Introduction}

An increasing body of evidence has recently accumulated to suggest that the development and progression of both microand macrovascular complications of diabetes could be due to the excessive formation of advanced glycation endproducts (AGEs) of proteins [1]. These post-translational modifications of proteins are derived nonenzymatically. In one of the proposed mechanisms for the formation of AGE, a reducing sugar such as glucose reacts with a free amino group of a protein, 
giving rise to a Schiff base, which through an intramolecular rearrangement can form a more stable, but still freely reversible, molecule: the Amadori product. Eventually, Amadori products can irreversibly progress to a family of compounds, collectively known as AGEs, many of which are fluorescent or participate in the formation of protein crosslinks [2]. Thus, nonenzymatic glycosylation can alter both the structure and bioactivity of the affected proteins [3-6]. In addition, the AGE moieties can be specifically recognised by plasma membrane receptors, which have been described in cells from various tissues [7-10]. The occupation of these receptors by AGEs in some cell types induces the secretion of cytokines and growth factors, which in turn can lead to an alteration in the proliferation and differentiation of nearby cells [11, 12].

Young developing patients with type 1 diabetes mellitus who show persistent hyperglycaemia throughout their growth stages frequently present a deficit in bone mass, which can eventually lead to a delay in maturation or to growth impairment [13-15]. These effects appear to be associated with a failure to acquire sufficient endosteal bone, and with complex vascular, nutritional and hormonal factors [16, 17]. Several lines of research have recently suggested that AGE accumulation could be involved in the diabetes-associated bone alterations. AGE-modified collagen has been shown to increase in the bones of diabetic rats, in relation to the duration of disease [18, 19]. In addition, the formation of AGE on bone matrix diminishes its ability to induce bone formation [20]. AGE-modified proteins have also been found to enhance osteoclast-induced bone resorption [21], to stimulate interleukin-6 (IL-6) production by human bone-derived cells [22] and to dose-dependently inhibit the phenotypic expression of a primary culture of rat osteoblasts and of preosteoblastic UMR201-10B cells [19, 23]. In keeping with these results, our group has demonstrated that AGE-modified proteins regulate the growth of mouse MC3T3E1 and rat UMR106 osteoblastic cell lines: while initially eliciting an increase in cellular proliferation and differentiation, a relatively long-term incubation of these cells with AGE-modified proteins induces a significant decrease in both parameters [24]. Furthermore, we have recently described the presence of membrane-associated receptors in both cell lines, which specifically participate in the recognition and degradation of AGE-modified proteins [10].

The physiological process of bone growth and development is strongly influenced, in autocrine and paracrine manners, by the insulin-like growth factors (IGF-I and IGF-II) and their binding proteins (IGFBPs). These polypeptides are produced by osteoblasts $[25,26]$, and are present in bone matrix $[27,28]$. In vitro, IGFs can modulate the expression of osteoblastic phenotype [29, 30], and stimulate the proliferation of osteoblasts in culture [31]. In vivo, exogenously added IGFs lead to an increase in bone formation and trabecular bone mass [32]. In addition, multiple IGFBPs modulate the actions of IGFs $[33,34]$. In fact, the relative abundance of IGFBPs, as well as their affinity for IGFs, most probably determine the bioactivity of IGFs on bone growth and development [35]. Recently, an association has been found between the progressive osteoblastic differentiation of MC3T3E1 cells, and temporal changes in their expression of IGF-I and IGFBPs [36]. This association implicates the IGF system in an autocrine-paracrine regulation of osteoblastic growth and development.

In the present study, we investigated the possible participation of the IGF system in the AGE-dependent modulation of osteoblastic growth and differentiation. In consequence, we examined the influence of AGE on the secretion of IGFI and IGFBPs by rat UMR106 and mouse MC3T3E1 cells in culture, throughout their different stages of osteoblastic development.

\section{Materials and methods}

Materials

Rabbit polyclonal antibody against human IGF-I (UBK487) was a generous gift from Dr. L. E. Underwood (Division of Paediatric Endocrinology, University of North Carolina at Chapel Hill, USA). Recombinant human IGF-I, bovine serum albumin (BSA), phenylmethyl-sulphonyl-fluoride (PMSF), $p$-nitrophenyl-phosphate (pNPP), glucose-6-phosphate (G6P), Triton X-100, acrylamide, sodium dodecyl sulphate (SDS), prestained molecular weight standards, Kodak XAR-5 photographic film and Sephadex G-50 were purchased from Sigma (St. Louis, MO, USA). Bio-Gel P-10 was obtained from Bio-Rad Laboratories (Hercules, CA, USA). Nitrocellulose paper was purchased from MSI (Westboro, MA, USA). Dulbecco's modified Eagle's medium (DMEM) and trypsinEDTA were from Gibco (Life Technologies, Grand Island, NY, USA). Fetal bovine serum (FBS) was purchased from Gen (Buenos Aires, Argentina). Centricon $10 \mathrm{kDa}$ cutoff filter cartridges were from Amicon (Beverly, MA, USA). ${ }^{125}$ I was from New England Nuclear. All other chemicals were of analytical grade.

\section{Preparation of AGE-protein}

AGE-BSA was prepared as we have previously described [24]. Briefly, BSA was incubated in sterile conditions in $150 \mathrm{mM}$ phosphate-buffered saline (PBS), $\mathrm{pH} 7.4$, with $100 \mathrm{mM}$ G6P at $37^{\circ} \mathrm{C}$ for 6 weeks in the presence of protease inhibitors (1.5 mM PMSF) and antibiotics (100 U/ml penicillin, $100 \mathrm{mg} / \mathrm{l}$ streptomycin). Control BSA was incubated under the same conditions without G6P. At the end of the incubation period, BSA and AGE-BSA were separated from non-covalently bound low molecular weight molecules by centrifugation-filtration with Centricon filter cartridges. The formation of protein-AGEs was assessed by their characteristic fluorescence-emission maximum at $420 \mathrm{~nm}$ upon excitation at $340 \mathrm{~nm}$. Fluorescence values of test substances were expressed as percentage relative fluorescence. Thus, the estimated level of AGE-BSA obtained in this in vitro incubation was $18.5 \%$ relative fluorescence intensity per milligram protein, as opposed to $3.2 \%$ for control BSA. 


\section{Cell culture}

MC3T3E1 osteoblastic mouse calvaria-derived cells were grown in $75 \mathrm{~cm}^{2}$ plastic flasks at $37^{\circ} \mathrm{C}$ in a humidified $5 \% \mathrm{CO}_{2}$ atmosphere in DMEM supplemented with $10 \% \mathrm{FBS}, 100 \mathrm{U} / \mathrm{ml}$ penicillin and $100 \mathrm{mg} / \mathrm{l}$ streptomycin, and passaged every 4-6 days. Previous studies have demonstrated that expression of osteoblastic markers begins after culturing these cells for 10 days with medium supplemented by $\beta$-glycerol-phosphate and ascorbic acid. In addition, mineralisation is achieved with these cells after extending this culture to 25 days. However, the cells only undergo active replication during the first 10 days of incubation [36, 37]. Thus, in order to study the secretion of IGF-I and IGFBPs in the different stages of this cell line, different protocols were chosen. To obtain preosteoblastic cells in active proliferation, cells were plated in 24 -well plates $\left(2.0 \times 10^{4}\right.$ cells/well $)$ and cultured for 3 days in DMEM with $10 \%$ FBS. In other experiments, MC3T3E1 cells were plated in $24-$ well plates $\left(2.0 \times 10^{4}\right.$ cells/well $)$, and cultured in DMEM supplemented with $10 \%$ FBS, $5 \mathrm{mM} \beta$-glycerol-phosphate and $25 \mathrm{mg} / \mathrm{l}$ ascorbic acid for either 15 days (differentiated cells) or 25 days (mineralising cells), changing the medium every 2 days. At the end of all incubations, cells were serum deprived, washed with DMEM and cultured for 24 hours with different concentrations of either control BSA or AGE-BSA. Conditioned media were saved for evaluation of cellular IGF-I and IGFBP secretion as described successively. The cell monolayer was lysed with $0.5 \mathrm{ml} 0.1 \%$ Triton $\mathrm{X}-100$. Aliquots of this total cell extract were then employed for protein determination using the Bradford method [38] and for measurement of the osteoblastic differentiation marker alkaline phosphatase (ALP) using pNPP as substrate [24]. In other experiments, the formation of mineralised nodules was microscopically evaluated in 15- and 25-day cultures of MC3T3E1 cells by the von Kossa technique [39]. Briefly, cells were fixed in $10 \%$ neutral buffered formalin and stained with $3 \% \mathrm{AgNO}_{3}$ for $30 \mathrm{~min}$.

UMR106 rat osteosarcoma-derived cells were grown in DMEM with $10 \%$ FBS and antibiotics. This cell line has been shown to conserve certain characteristics of differentiated osteoblastic phenotype [40]. After 5-7 days, cells were sub-cultured using trypsin-EDTA and replated to begin the experiments. Cells were split at subconfluence and plated in 24-well plates $\left(2.5 \times 10^{4}\right.$ cells/well) in DMEM with $10 \%$ FBS. Subconfluent cells were then serum deprived, washed with DMEM and incubated for 24 hours with increasing concentrations of either control BSA or AGE-BSA. Conditioned media and cell monolayers were processed as described for MC3T3E1 cells, in order to evaluate cellular production of IGF-I and IGFBPs, and cell-associated ALP activity.

\section{IGF-I assay}

IGF-I content of conditioned media was determined by a specific radioimmunoassay (RIA) as we have previously described [41]. IGFBPs were previously eliminated from the samples by a recently described acid gel filtration-centrifugation method [42]. Briefly, conditioned media were dried in a Savant Speed-Vac centrifuge, dissolved in $100 \mu$ elution buffer $(1 \mathrm{M}$ acetic acid, $0.1 \mathrm{M} \mathrm{NaCl})$ and applied to a minicolumn loaded with $4 \mathrm{ml}$ BioGel P-10 (45- to 90- $\mu$ l particle size) hydrated with elution buffer containing $10 \mathrm{~g} / \mathrm{l}$ BSA. Void volume was discarded by centrifugation at $1250 \mathrm{xg}$ for 5 minutes, and IGFBPs were eliminated by application of $250 \mu \mathrm{l}$ elution buffer and further centrifugation for 5 minutes. IGF-I was recovered from the column by elution-centrifugation with $1.5 \mu \mathrm{l}$ elution buffer. This IGF-containing fraction was then neutralised and dried by Speed-Vac centrifugation. Samples were stored at $-20^{\circ} \mathrm{C}$ until IGF-I RIA was performed.

In order to validate this method for our assay conditions, ${ }^{125}$ I-IGF-I was added to a serum sample diluted in elution-buffer prior to extraction. The sample was applied to a column and then eluted in a stepwise manner, by successive elution-centrifugation with $10 \times 50 \mu \mathrm{l}$ and $10 \times 250 \mu \mathrm{l}$ aliquots of buffer. In each aliquot, the ${ }^{125}$ I-IGF-I-associated radioactivity, as well as total IGF-I binding capacity [42], were measured to determine the elution volumes which optimally separate IGFs from IGFBPs (Fig. 1). The recovery of exogenously added ${ }^{125}$ I-IGF-I was greater than $90 \%$. No IGFBPs from the serum sample were detected by binding capacity analysis of the IGF-I pool obtained by BioGel separation.

For assay purposes, recombinant-human IGF-I was used as a standard and tracer in the RIA. The hormone was iodinated with ${ }^{125}$ I by means of the chloramine-T method [43] at a specific activity of $400-450 \mu \mathrm{Ci} / \mu \mathrm{g}$, and purified on a Sephadex G-50 column [44]. The anti-IGF-I rabbit polyclonal antibody (UBK487) was employed at 1:8000 dilution. The intra- and interassay coefficients of variation for this method were $10.9 \%$ and $13 \%$, respectively. Under our working conditions, serial dilutions of rhIGF-I standard (0.025-50 ng/tube) and extracted conditioned medium gave parallel displacement curves. Levels of IGF-I in BSA-supplemented non-conditioned serum-free culture media were below the detection limit.

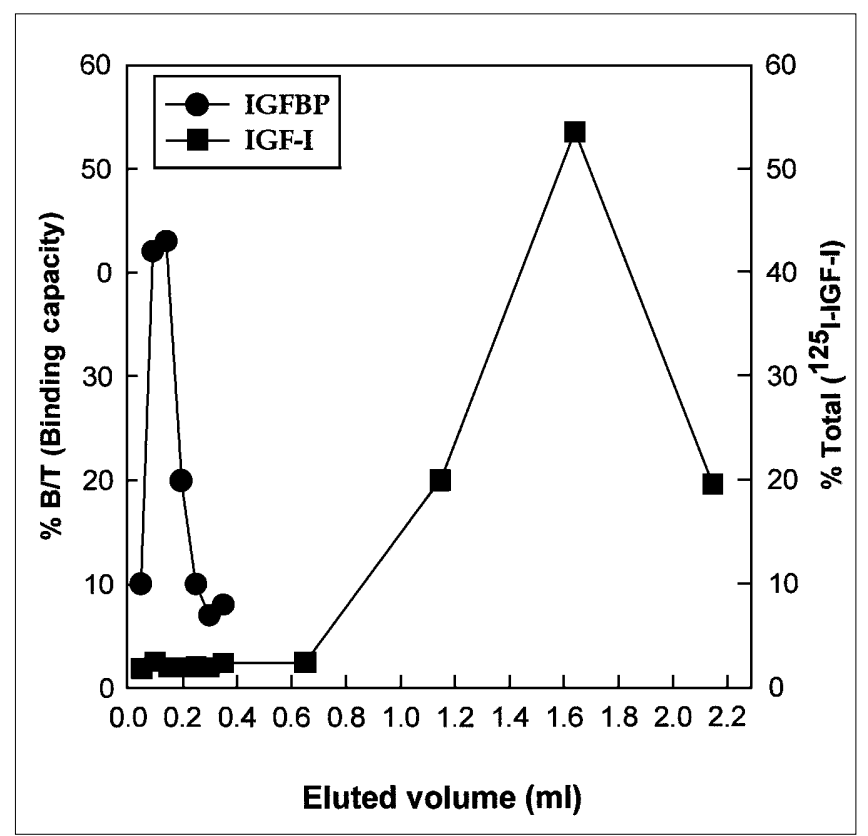

Fig. 1 Separation of IGF-I from IGFBPs in a serum sample by BioGel P-10 extraction. An aliquot of serum was mixed with ${ }^{125}$ I-IGFI and elution buffer. The sample was then applied to a minicolumn containing hydrated BioGel P-10, and centrifuged for 5 minutes as described in Materials and methods. The column was eluted sequentially with $10 \times 50 \mu \mathrm{l}$ and $10 \times 250 \mu \mathrm{l}$ aliquots of elution buffer. Each fraction was then subjected to the binding capacity assay to evaluate total IGFBPs, and counted in a gamma counter for ${ }^{125} \mathrm{I}$ IGF-I quantification 


\section{Western ligand blot for IGFBPs}

Conditioned media were dried in a Savant Speed-Vac centrifuge, and dissolved in $50 \mu \mathrm{l}$ Laemmli's non-reduced sample buffer [45] immediately prior to electrophoresis. These samples were then boiled for 3 minutes before being loaded onto a $12.5 \%$ SDS-polyacrylamide gel. Under these conditions, endogenous IGFs are dissociated by SDS, so the molecular weight reflects that of the binding component alone. Samples were electrophoresed at $150 \mathrm{~V}$ until the dye front reached the bottom of the gel. Prestained molecular weight marker proteins and a rat serum sample were run in parallel lanes. Proteins were transferred to nitrocellulose membranes in a $15 \mathrm{mM}$ Tris-base, 120 $\mathrm{mM}$ glycine buffer, $\mathrm{pH} 8.3$, containing 5\% methanol (v/v) [46]. Electroblotting was performed under constant current of $50 \mathrm{~mA}$ for 16-18 hours. The nitrocellulose paper was then blocked at $4^{\circ} \mathrm{C}$ [46] and incubated with ${ }^{125}$ I-IGF-I $\left(2 \times 10^{5} \mathrm{cpm} / \mathrm{ml}\right.$, as described previously) in $1 \%$ IGFBP-free BSA, $0.1 \%$ Tween-20 in TS buffer $(150 \mathrm{mM}$ $\mathrm{NaCl}, 10 \mathrm{mM}$ Tris-HCl, pH 7.4, $0.5 \mathrm{mg} / \mathrm{ml}$ sodium azide). Following this incubation, the membranes were washed and autoradiographed using XAR-5 Kodak film and a Dupont intensifying screen at $-70^{\circ} \mathrm{C}$ for 2-5 days. To measure the amount of ${ }^{125}$ I-IGF-I bound to each IGFBP fraction, the nitrocellulose paper was cut into strips, which were counted in a Cobra-II Packard gamma counter.

\section{Statistical analysis}

Four independent experiments were run by duplicate for each experimental condition. Results are expressed as mean and SEM. Statistical analysis of the data was performed employing Student's $t$ test.

\section{Results}

In order to characterise the successive stages of MC3T3E1 osteoblastic progression, cell-associated specific ALP activity was determined at all culture time points, and mineralisation was evaluated in 15- and 25-day cultures by staining cell layers using the von Kossa method. In our culture conditions, cellular ALP was undetectable in proliferating (3-day) preosteoblasts, increased to $2.2 \pm 0.2 \mu \mathrm{mol} \mathrm{pNP} / \mathrm{min} \mathrm{g}$ protein in mature (15-day) cells, and reached a plateau of $8.5 \pm 0.6 \mu \mathrm{mol}$ $\mathrm{pNP} / \mathrm{min} \mathrm{g}$ protein in long-term (25-day) cultures. In addition, von Kossa staining demonstrated the presence of extracellular mineral nodules in 25-day cultures, indicating that they had attained mineralisation (data not shown). This extracellular mineral was absent in 15-day cultures.

In UMR106 cells, basal cell-associated ALP was 195 \pm 7 $\mu \mathrm{mol} \mathrm{pNP} / \mathrm{min} \mathrm{g}$ protein. This established osteosarcoma cell line expresses several markers of osteoblastic phenotype, namely bone-specific ALP, type I collagen synthesis and PTH-inducible cAMP levels [40].

We next studied the possible modulation of cellular IGFI secretion in UMR106 osteosarcoma cells, by a 24-hour incubation with $100-500 \mu \mathrm{g} / \mathrm{ml}$ of AGE-modified BSA. In these cells, the basal IGF-I secretion was $2.5 \pm 0.4 \mathrm{ng} / \mathrm{mg}$ protein $(\mathrm{n}=8)$. AGE-BSA significantly decreased IGF-I secretion at a concentration of $100 \mu \mathrm{g} / \mathrm{ml}(56 \% \pm 8 \%$ of control BSA; $p<0.05)$. At 200 and $500 \mu \mathrm{g} / \mathrm{ml}$ of AGE-modified BSA, the secretion of IGF-I showed a tendency to decrease. However, it was not significantly different from control BSA $(72 \% \pm 19 \%$ and $80 \% \pm 23 \%$ of basal levels, for 200 and $500 \mu \mathrm{g} / \mathrm{ml}$, respectively).

In further experiments, we analysed the basal secretion of IGF-I by MC3T3E1 cells throughout their successive stages of development. Basal IGF-I secretion followed a biphasic temporal pattern (Table 1). We also studied the possible modifications of IGF-I secretion as a consequence of a 24-hour incubation with AGE-BSA. When AGE-BSA was incubated with preosteoblastic MC3T3E1 cells in active proliferation (Fig. 2a), a significant decrease in IGF-I secretion was observed at 200 and $500 \mu \mathrm{g} / \mathrm{ml}$. In post-mitotic MC3T3E1 cells with a mature phenotype (15-day differentiated cultures), secretion of IGF-I was apparently unaffected by the presence of AGE-BSA vs. control BSA (105\%, $80 \%$ and $83 \%$ of values from control BSA for 100, 200 and $500 \mu \mathrm{g} / \mathrm{ml})$. On the contrary, IGF-I secretion by MC3T3E1 osteoblasts which had attained mineralisation (Fig. 2b) was significantly increased when they were incubated with 100 and $200 \mu \mathrm{g} / \mathrm{ml}$ of AGE-BSA.

In the present experiments, when both cell lines were incubated for 24 hours with 100-500 $\mu \mathrm{g} / \mathrm{ml}$ AGE-modified BSA, different effects were seen on their secretion of IGFBPs, as assessed by western ligand blotting. In the case of UMR106 osteosarcoma cells incubated with either AGEBSA or control BSA, ligand blot analysis showed the predominant secretion of a 24-kDa IGFBP and a minor 29-kDa band (Fig. 3a). When the IGFBP bands corresponding to each experimental condition were semiquantified (Fig. 3b), a significant difference between AGE-BSA vs. control BSA was found at a protein concentration of $100 \mu \mathrm{g} / \mathrm{ml}(80 \%$ of control BSA).

In the non-transformed MC3T3E1 mouse calvariaderived cell line, western ligand blot analysis showed a major band of $\sim 29 \mathrm{kDa}$. This pattern of IGFBP secretion, which most probably was due to variable contributions by IGFBP-2 and -5 , was maintained throughout the successive stages of MC3T3E1 osteoblastic development (Figs. 4a, 5a and 6a). 3-, 15- and 25-day cultures of MC3T3E1 cells were incubated with different concentrations of either AGE-BSA or control

Table 1 Basal IGF-I secretion by MC3T3E1 osteoblast-like cells in culture. Cells were incubated for $24 \mathrm{~h}$ with $100 \mu \mathrm{g} / \mathrm{ml} \mathrm{BSA}$ in DMEM. IGF-I was separated from IGFBP and measured by RIA. Values are the mean (SEM) of four independent cultures performed in duplicate

Cellular stage of development IGF-I (ng/mg cell protein)

Proliferated

Differentiated

$10.3(4.0)$

Mineralised

$3.5(1.2)$

$24.0(1.0)$ 

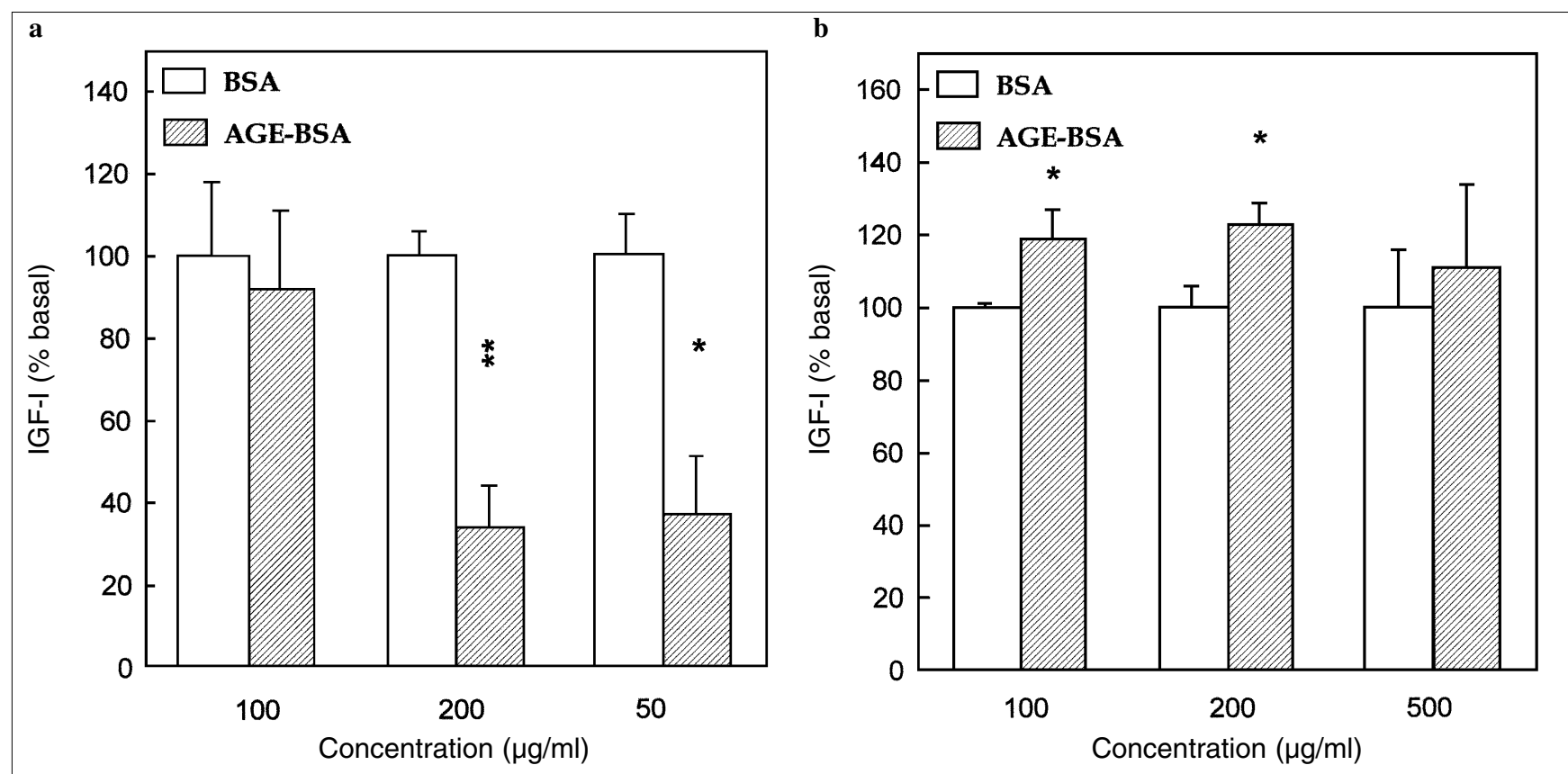

Fig. 2a, b Effect of AGE-BSA on IGF-I secretion by cultures of MC3T3E1 cells in different developmental stages. a Proliferating MC3T3E1. b Mineralised MC3T3E1. Osteoblast-like cells were cultured for different periods of time as described in Materials and methods. Cells were then incubated for 24 hours in serum-free DMEM with either BSA or AGE-BSA at the doses indicated in the figures. Conditioned media were extracted and analysed to determine IGF-I concentration. Data are expressed as percent of control BSA and each bar corresponds to the mean \pm SEM $(\mathrm{n}=8)$. Differences between BSA and AGE-BSA are as follows: $* p<0.02 ; * * p<0.002$

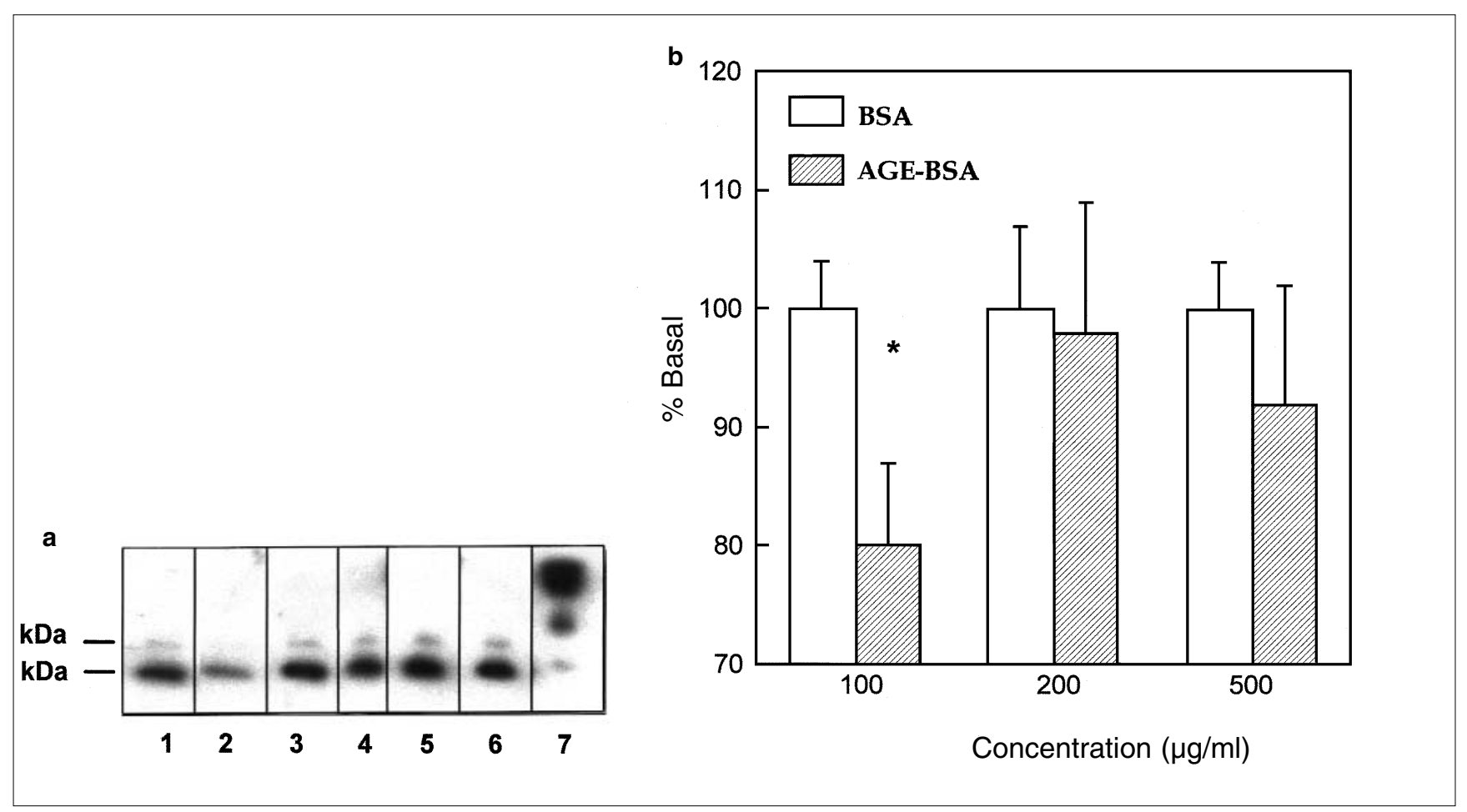

Fig. 3a, b Effect of AGE-BSA on the secretion of IGFBPs in UMR106 cultures. a Cells were incubated in serum-free DMEM with either BSA (lanes 1, 3 and 5) or AGE-BSA (lanes 2, 4 and 6) at protein concentrations of $100 \mu \mathrm{g} / \mathrm{ml}$ (lanes 1 and 2), $200 \mu \mathrm{g} / \mathrm{ml}$ (lanes 3 and 4 ) or $500 \mu \mathrm{g} / \mathrm{ml}$ (lanes 5 and 6). After a 24-hour incubation, conditioned media were analysed for the presence of IGFBPs by western ligand blotting employing ${ }^{125}$ I-IGF-I as a ligand. Lane 7, $10 \mu \mathrm{l}$ rat serum. Bands were evidenced by autoradiography. b Nitrocellulose papers were cut into strips and counted in a gamma counter for semi-quantification. The data for AGE-BSA is expressed as a percentage of the corresponding control BSA condition, and given as the mean \pm SEM $(n=8)$. $* p<0.05$ vs. control BSA conditions 


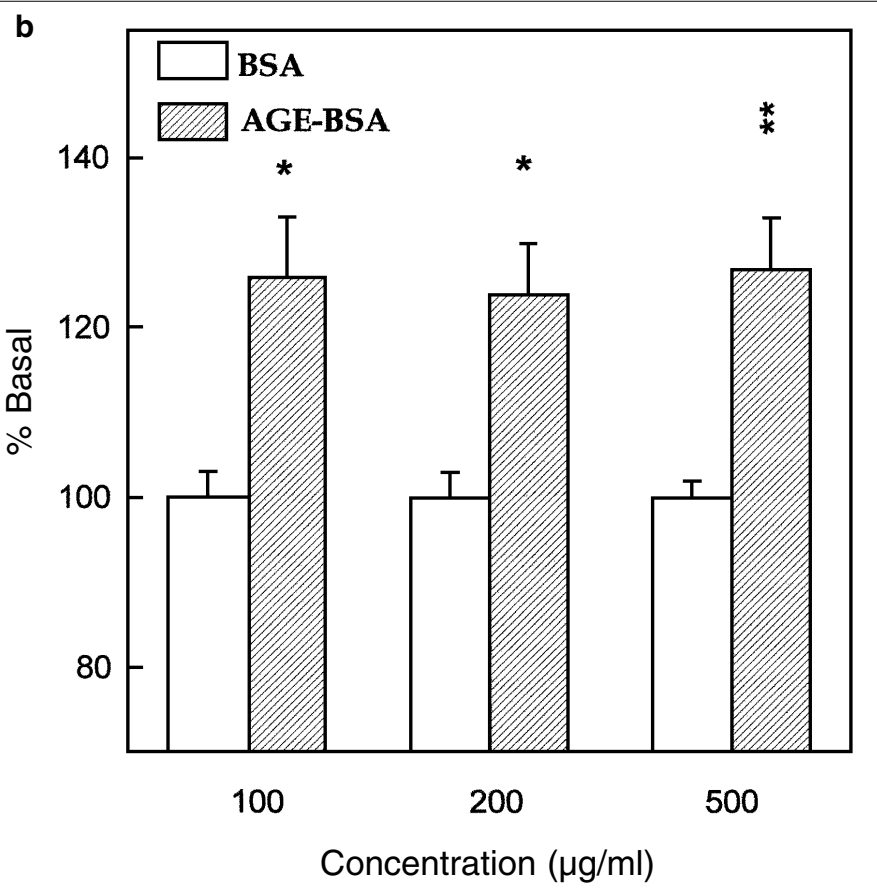

Fig. 4a, b Effect of AGE-BSA on the secretion of IGFBPs in proliferating MC3T3E1 cultures. a Cells were incubated in serum-free DMEM with either BSA (lanes 1, 3 and 5) or AGE-BSA (lanes 2, 4 and 6) at protein concentrations of $100 \mu \mathrm{g} / \mathrm{ml}$ (lanes 1 and 2), $200 \mu \mathrm{g} / \mathrm{ml}$ (lanes 3 and 4) or $500 \mu \mathrm{g} / \mathrm{ml}$ (lanes 5 and 6). After a 24-hour incubation, conditioned media were analysed for the presence of IGFBPs by western ligand blotting employing ${ }^{125}$ I-IGF-I as a ligand. Lane 7, $10 \mu \mathrm{l}$ rat serum. Bands were evidenced by autoradiography. b Nitrocellulose papers were cut into strips and counted in a gamma counter for semiquantification. Data for AGE-BSA are expressed as a percentage of the corresponding control BSA condition, and given as the mean $\pm \operatorname{SEM}(\mathrm{n}=8)$. Differences between BSA and AGE-BSA are as follows: $* p<0.02 ; * * p<0.01$

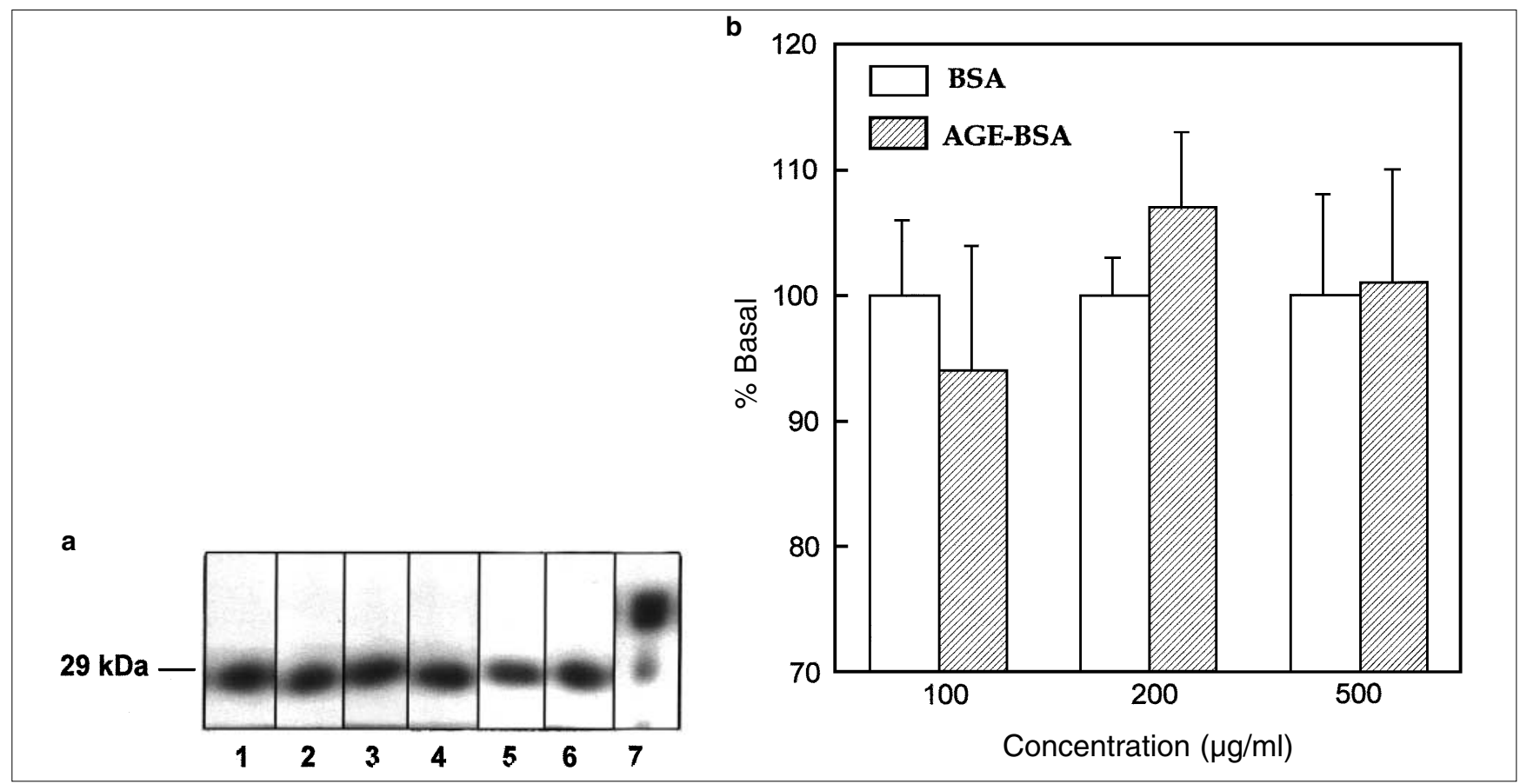

Fig. 5a, b Effect of AGE-BSA on the secretion of IGFBPs in mature (differentiated) MC3T3E1 cultures. a Cells were incubated in serumfree DMEM with either BSA (lanes 1, 3 and 5) or AGE-BSA (lanes 2, 4 and 6) at protein concentrations of $100 \mu \mathrm{g} / \mathrm{ml}$ (lanes 1 and 2), 200 $\mu \mathrm{g} / \mathrm{ml}$ (lanes 3 and 4) or $500 \mu \mathrm{g} / \mathrm{ml}$ (lanes 5 and 6). After a 24-hour incubation, conditioned media were analysed for the presence of IGFBPs by western ligand blotting employing ${ }^{125}$ I-IGF-I as a ligand. Lane 7, $10 \mu \mathrm{l}$ rat serum. Bands were evidenced by autoradiography. b Nitrocellulose papers were cut into strips and counted in a gamma counter for semiquantification. Data for AGE-BSA are expressed as a percentage of the corresponding control BSA condition, and given as the mean \pm SEM $(n=8)$ 


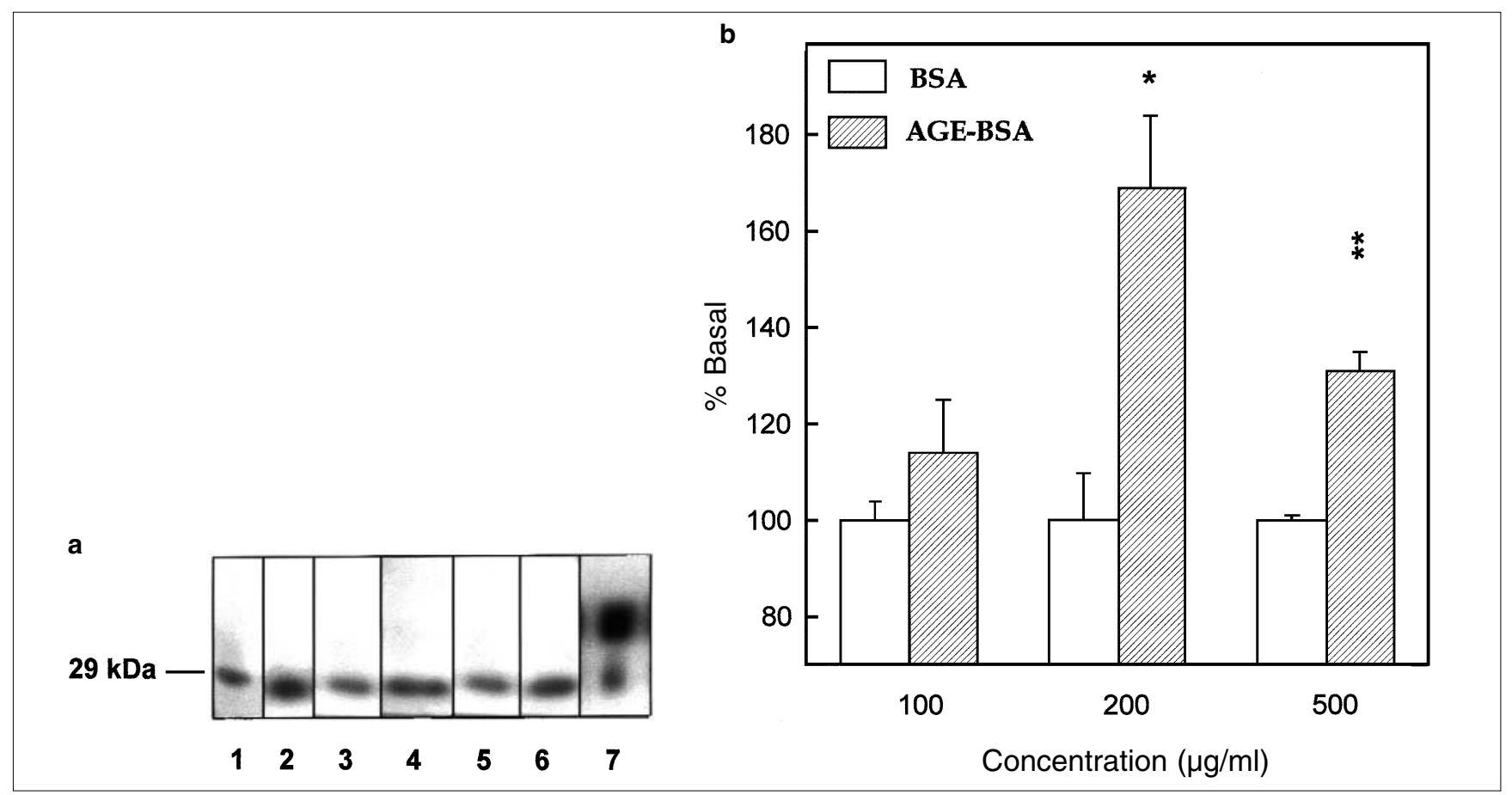

Fig. 6a, b Effect of AGE-BSA on the secretion of IGFBPs in mineralised MC3T3E1 cultures. a Cells were incubated in serum-free DMEM with either BSA (lanes 1, 3 and 5) or AGE-BSA (lanes 2, 4 and 6) at protein concentrations of $100 \mu \mathrm{g} / \mathrm{ml}$ (lanes 1 and 2), $200 \mu \mathrm{g} / \mathrm{ml}$ (lanes 3 and 4) or $500 \mu \mathrm{g} / \mathrm{ml}$ (lanes 5 and 6). After a 24-hour incubation, conditioned media were analysed for the presence of IGFBPs by western ligand blotting employing ${ }^{125}$ I-IGF-I as a ligand. Lane 7, $10 \mu \mathrm{l}$ rat serum. Bands were evidenced by autoradiography. b Nitrocellulose papers were cut into strips and counted in a gamma counter for semiquantification. Data for AGE-BSA are expressed as a percentage of the corresponding control BSA condition, and given as the mean \pm SEM $(n=8)$. Differences between BSA and AGE-BSA are as follows: $* p<0.02 ; * * p<0.001$

BSA for 24 hours. Conditioned media were then submitted to ligand blotting, and the resulting IGFBP bands were semiquantified. In proliferating preosteoblastic cells (Fig. 4b), AGE-BSA (100-500 $\mu \mathrm{g} / \mathrm{ml})$ significantly increased the secretion of 29-kDa IGFBPs (124\%-127\% of control BSA). On the other hand, AGE-BSA provoked no changes in total 29-kDa IGFBP production in 15-day cultures of MC3T3E1 cells (Fig. 5b). However, when AGE-BSA $(200-500 \mu \mathrm{g} / \mathrm{ml})$ was incubated with cultures which had attained mineralisation (Fig. 6b), a biphasic stimulation was observed in the secretion of $29-\mathrm{kDa}$ IGFBPs $(131 \%-169 \%$ of control BSA).

\section{Discussion}

The current study provides evidence that implicates AGEmodified protein in the modulation of IGF-I and IGFBP secretion by MC3T3E1 and UMR106 osteoblastic cells. This modulatory effect was found to depend on the stage of osteoblastic progression, and could be at least partly responsible for the AGE-dependent changes in cellular proliferation and differentiation which we have previously described in these cell lines [24].
It has been firmly established that the process of bone formation depends on the number and activity of osteoblasts, and on the activity of the IGF system [47]. Thus, we hypothesised that the AGE-induced modulation of osteoblastic cell growth, which we have previously described [10, 24], could be mediated by regulating one or more components of the locally produced IGF system.

The osteoblastic cell lines used in these experiments have previously been found to secrete different IGFBPs. UMR106 cells mainly synthesise IGFBP-4, a 24-kDa protein that inhibits IGF-I action in most systems [35, 48]. In addition, they also produce lower amounts of a $29-\mathrm{kDa}$ binding protein, which has been shown to be IGFBP-5. In this cell line, low concentrations $(100 \mu \mathrm{g} / \mathrm{ml})$ of AGE-BSA significantly inhibited both IGF-I and $24-\mathrm{kDa}$ binding protein (IGFBP-4) secretion. This is in agreement with our previous observation of AGE-BSA modulation of UMR106 cell proliferation [24], which also occurred in a narrow range of concentrations. We have also shown in these cells that this dose of AGE-BSA is sufficient to significantly occupy cellular AGE-specific receptors [10] and is also enough to provoke a long-term decrease in cellular proliferation and ALP activity [24]. Thus, it is interesting to speculate that in this cell line the AGE-mediated decrease 
in IGF-I secretion could contribute to the observed biological effects, possibly as a consequence of the occupation of AGE-specific receptors.

The use of the MC3T3E1 cell line, which progressively differentiates through successive stages of osteoblastic development, allowed us to further test our hypothesis. This progressive development was confirmed in the present study, by measurement of temporal changes in ALP activity and formation of nodules of mineralisation. We have previously demonstrated that AGE-BSA modifies the proliferation (in 3-day cultures) and ALP activity (in 25-day cultures) of this osteoblastic cell line, in a sequence similar to UMR106 cells. That is, short incubations with AGE-modified proteins provoke an increase in these biological effects, generally followed by a decrease when incubations with AGE are prolonged [24]. Moreover, we have also found AGE-specific receptors in these cells, which are differentially regulated throughout the osteoblastic stages of development, and whose half-maximal binding is similar to the AGE doses needed for a biological effect [10].

MC3T3E1 cells in this study secreted basal IGF-I levels which were in the order of the IGF-II concentration produced by human calvaria-derived bone cells [49]. In agreement with previous reports both in MC3T3E1 cells [36] and in a primary cultures of osteoblasts [50], we found biphasic temporal changes in the cellular secretion of IGF-I: minimum levels were observed in 15-day cultures, while the maximum concentrations were attained in mineralised (25day) cultures (Table 1).

MC3T3E1 cells principally secrete IGFBP-2 and -5, as well as a weak 24-kDa band which corresponds to IGFBP4. The two major binding proteins are indistinguishable by ligand blot analysis, since they migrate as a single band with an apparent molecular weight of $29 \mathrm{kDa}$. The relative secretion of IGFBP-2 and -5 by this cell line has been found to be dependent on the stage of osteoblastic differentiation [36]: by immunoblot analysis, IGFBP-5 was found to peak between days 8 and 14 of culture, decreasing thereafter. On the other hand, in the same study IGFBP-2 increased constantly until day 25 of culture (mineralised cells), and was the predominant binding protein in the later stages of development [36]. In our experiments, these cells secreted 29$\mathrm{kDa}$ binding proteins, most probably corresponding to variable amounts of IGFBP-2 and -5 .

In actively proliferating MC3T3E1 cells, AGE-modified BSA induced a significant decrease in IGF-I secretion (Fig. 2a), and an increase in IGFBP levels (Fig. 4). IGFBP-2 has been shown to inhibit the mitogenic effects of IGF-I in certain systems. In addition, recent studies have demonstrated that IGFBP-5 secreted into the conditioned medium (but unbound to the extracellular matrix [ECM]), inhibits the mitogenic effect of IGF-I in smooth muscle cells [51]. Importantly, MC3T3E1 cells produce relatively low amounts of ECM during their proliferative phase [37]. Thus, both $29-\mathrm{kDa}$ binding proteins may exhibit similar effects on
IGF-I-induced cell proliferation. Considering the great AGE-induced inhibition of IGF-I secretion by these preosteoblastic cells, and the increase in the total amount of IGFBP detected by ligand blot, it is conceivable to suppose that a diminished amount of free IGF-I should be available for binding to specific type-I IGF receptors, provoking a decrease in osteoblastic replication. This situation is compatible with the inhibition of MC3T3E1 proliferation ultimately induced by AGE-BSA, which we have reported previously [24].

When MC3T3E1 osteoblasts attained the mature stage of differentiation (15-day cultures), no significant effects were observed by AGE-modified proteins on either IGF-I or IGFBP secretion (Fig. 5). In addition, at this period of MC3T3E1 osteoblastic development, we were not able to detect any significant effects of AGE-BSA on ALP activity (our unpublished observations).

Finally, in mineralised MC3T3E1 cells (25-day cultures), AGE-BSA was found to increase the production of both IGF-I (Fig. 2b) and IGFBP (Fig. 6). The effect on IGFBP secretion showed a biphasic pattern which is in agreement with our previous results on the AGE-induced ALP modulation in mineralised MC3T3E1 osteoblasts. At this stage of osteoblastic development, the 29-kDa band which we detected by ligand blot analysis probably represents IGFBP-2, according to the western immunoblot observations of previous studies [36]. These changes in the secretion of IGF-I and 29-kDa IGFBPs by mineralising osteoblasts could be related to our previous report of an ultimate decrease in ALP activity in such cells after their incubation with AGE-BSA [24], and with other reports of an AGE-induced decrease in the expression of several parameters of bone phenotype such as ALP, osteocalcin, osteopontin, and nodule formation by mineralised osteoblasts [19, 23].

From the presented results, it can be seen that differentiated MC3T3E1 cells (15-day culture) show no AGEinduced modifications on IGF or IGFBP secretion, and this is coincident with a lack of alterations in the measured biological effects. On the other hand, the AGE-associated modulation of the IGF/IGFBP system, which we have found in the proliferating and mineralised MC3T3E1 cell model, could be associated with the observed dysregulation of osteoblast development. Thus, this experimental model of MC3T3E1 cells appears to support the concept that the biological effect of AGEs in osteoblastic cells, possibly initiated through a recognition of AGE structures by their specific receptors, could be mediated by the IGF system in an autocrine-paracrine manner.

In summary, our present observations provide evidence for a direct effect of advanced glycation endproducts on the secretion of IGF-I and its binding proteins, in a pattern which depends on the stage of osteoblastic development. They suggest a role for the IGF axis as a potential mediator in the seemingly deleterious effects of AGE-modified proteins on bone. 
Acknowledgements This study was partially supported by grants from Universidad Nacional de La Plata, CICPBA, CONICET (PIP1044/98), Agencia Nacional de Promoción Científica (PICT 00375) and Ministerio de Salud y Acción Social de la Nación (Subsecretaría de Investigación y Tecnología, Beca Ramón Carrillo-Arturo Oñativia 2000). AMC is a member of the Carrera del Investigador, CICPBA, and SBE is a member of the Carrera del Investigador, CONICET. The authors are especially indebted to Dr. L.E. Underwood from the University of North Carolina at Chapel Hill, NC, USA, for the provision of rabbit polyclonal antibody against human IGF-I.

\section{References}

1. Vlassara H, Bucala R, Striker L (1994) Pathogenic effects of advanced glycosylation: biochemical, biologic and clinical implications for diabetes and ageing. Lab Invest 70:138-151

2. Monnier V (1993) Glycosylation non-enzymatique des protéines. Presse Méd 22:1413-1418

3. Monnier VM, Kohn RR, Cerami A (1984) Accelerated agerelated browning of human collagen in diabetes mellitus. Proc Natl Acad Sci USA 81:583-587

4. Brownlee M, Vlassara H, Cerami A (1983) Non-enzymatic glycosylation reduces the susceptibility of fibrin to degradation by plasmin. Diabetes 32:680-684

5. Cortizo AM, Gagliardino JJ (1995) Changes induced by nonenzymatic glycosylation of IGF-binding protein-3: effects on its binding properties and on its modulatory effect on IGF-I mitogenic action. J Endocrinol 144:119-126

6. McCarthy AD, Cortizo AM, Giménez Segura G, Bruzzone L, Etcheverry SB (1998) Non-enzymatic glycosylation of alkaline phosphatase alters its biological properties. Mol Cell Biochem 181:63-69

7. Vlassara H, Brownlee M, Cerami A (1985) High-affinity receptor-mediated uptake and degradation of glucose-modified proteins: a potential mechanism for the removal of senescent macromolecules. Proc Natl Acad Sci USA 82:5588-5592

8. Espósito C, Gerlach H, Brett J, Stern D, Vlassara H (1989) Endothelial receptor-mediated binding of glucose-modified albumin is associated with increased monolayer permeability and modulation of cell-surface coagulant properties. J Exp Med 170:1387-1407

9. Skolnik KY, Yang Z, Makita Z, Radoff S, Vlassara H (1991) Human and rat mesangial cell receptors for glucose-modified proteins: potential role in kidney tissue remodelling and diabetic nephropathy. J Exp Med 174:931-939

10. McCarthy AD, Etcheverry SB, Cortizo AM (1999) Advanced glycation endproduct-specific receptors in rat and mouse osteoblast-like cells: regulation with stages of differentiation. Acta Diabetol 36:45-52

11. Vlassara H, Brownlee M., Manogue KR, Dinarello CA, Pasagian A (1988) Cachectin/TNF and IL-1 induced by glucose-modified proteins: role in normal tissue remodelling. Science 240:1546-1548

12. Kirstein M, Aston C, Hintz R, Vlassara H (1992) Receptorspecific induction of insulin-like growth factor-I in human monocytes by advanced glycosylation end product-modified proteins. J Clin Invest 90:439-446
13. Levin ME, Boisseau VC, Avioli LV (1976) Effect of diabetes mellitus on bone mass in juvenile and adult-onset diabetes. $\mathrm{N}$ Engl J Med 294:241-245

14. Rosenbloom AL, Lezotte DC, Weber FT et al (1977) Diminution of bone mass in childhood diabetes. Diabetes 26:1052-1055

15. Hui SL, Epstein S, Johnstone CC Jr (1985) A prospective study of bone mass in patients with type I diabetes. J Clin Endocrinol Metab 60:74-80

16. Wiske PS, Wentworth SM, Norton JA, Epstein S, Johnstone CC (1982) Evaluation of bone mass and growth in young diabetics. Metabolism 31:848-854

17. Kayath MJ, Dib SA, Vieiaa JG (1994) Prevalence and magnitude of osteopenia associated with insulin-dependent diabetes mellitus. J Diabetes Compl 8:97-104

18. Tomasek JJ, Meyers SW, Basinger JB, Green DJ, Shew RL (1994) Diabetic and age-related enhancement of collagenlinked fluorescence in cortical bones of rats. Life Sci 55:855-861

19. Katayama Y, Akatsu T, Yamamoto M, Kugai N, Nagata N (1996) Role of nonenzymatic glycosylation of type I collagen in diabetic osteopenia. J Bone Miner Res 11:931-937

20. Fong Y, Edelstein D, Wang EA, Brownlee M (1993) Inhibition of matrix-induced bone differentiation by advanced glycation end-products in rats. Diabetologia 36:802-807

21. Miyata T, Notoya K, Yoshida K et al (1997) Advanced glycation end products enhance osteoclast-induced bone resorption in cultured mouse unfractionated bone cells and in rats implanted subcutaneously with devitalised bone particles. J Am Soc Nephrol 8:260-270

22. Takagi M, Kasayama S, Yamamoto T et al (1997) Advanced glycation endproducts stimulate interleukin- 6 production by human bone-derived cells. J Bone Miner Res 12:439-446

23. Katayama Y, Celic S, Nagata M, Martin TJ, Findlay DM (1997) Nonenzymatic glycation of type I collagen modifies interaction with UMR 201-10B preosteoblastic cells. Bone 21:237-242

24. McCarthy AD, Etcheverry SB, Bruzzone L, Cortizo AM (1997) Effects of advanced glycation end-products on the proliferation and differentiation of osteoblast-like cells. Mol Cell Biochem 170:43-51

25. McCarthy TL, Centrella M, Canalis E (1989) Insulin-like growth factor (IGF) and bone. Connect Tissue Res 20:277-282

26. Lakatos P, Caplice MD, Khanna V, Stern PH (1993) Thyroid hormones increase insulin-like growth factor I content in the medium of rat bone tissue. J Bone Miner Res 8:1475-1481

27. Canalis E, McCarthy TL, Centrella M (1988) Isolation of growth factors from adult bovine bone. Calcif Tissue Int 19:346-351

28. Bautista CM, Baylink DJ, Mohan S (1991) Isolation of a novel insulin-like growth factor (IGF) binding protein from human bone: a potential candidate for fixing IGF-II in human bone. Biochem Biophys Res Comm 176:756-763

29. Pfeilschifter J, Oechsner M, Naumann A et al (1990) Stimulation of bone matrix apposition in vitro by local growth factors: a comparison between insulin-like growth factor-I, platelet-derived growth factor, and transforming growth factor. Endocrinology 127:69-75

30. Thiebaud D, Ng KW, Findlay DM, Harker M, Martin TJ (1990) Insulin-like growth factor I regulates mRNA levels of osteonectin and pro-alpha 1(I)-collagen in clonal preosteoblastic calvarial cells. J Bone Miner Res 5:761-767 
31. Hook JM, Centrella M, Canalis E (1988) Insulin-like growth factor I has independent effects on bone matrix formation and cell replication. Endocrinology 125:254-259

32. Baylink DJ, Finkelman RD, Mohan S (1993) Growth factors to stimulate bone formation. J Bone Miner Res 8:S565-S572

33. Andress DL, Birnbaum RS (1992) Human osteoblast-derived insulin-like growth factor (IGF) binding protein-5 stimulates osteoblast mitogenesis and potentiates IGF action. J Biol Chem 267:22467-22472

34. Chen TL, Chang LY, DiGregorio DA, Perlmen AJ, Huang YF (1993) Growth factor modulation in insulin-like growth factor-binding proteins in rat osteoblast-like cells. Endocrinology 130:1382-1389

35. Mohan S, Nakao Y, Honda Y et al (1995) Studies on the mechanisms by which insulin-like growth factor (IGF) binding protein-4 (IGFBP-4) and IGFBP-5 modulate IGF actions in bone cells. J Biol Chem 270:20424-20431

36. Thrailkill KM, Siddhanti SR, Fowlkes JL, Quarles LD (1995) Differentiation of MC3T3-E1 osteoblasts is associated with temporal changes in the expression of IGF-I and IGFBPs. Bone 17:307-313

37. Quarles LD, Yahay DA, Lever LW, Caton R, Wenstrup RJ (1992) Distinct proliferative and differentiated stages of murine MC3T3E1 cells in culture: an in vitro model of osteoblast development. J Bone Miner Res 7:683-692

38. Bradford M (1976) Rapid and sensitive method for quantitation of microgram quantities of protein utilizing the principle of protein-dye binding. Anal Biochem 72:248-254

39. Aronow MA, Gerstenfeld LC, Owen TA et al (1990) Factors that promote progressive development of the osteoblast phenotype in cultured fetal rat calvaria cells. J Cell Physiol 143:213-221

40. Partridge NC, Alcorn D, Michelangeli VP, Ryan G, Martin TJ (1983) Morphological and biochemical characterization of four clonal osteogenic sarcoma cell lines of rat origin. Cancer Res 43:4308-4312

41. Cortizo AM, Lee PDK, Cédola NV, Jasper H, Gagliardino JJ (1998) Relationship between non-enzymatic glycosylation and changes in serum insulin-like growth factor-I (IGF-I) and IGF-binding protein-3 levels in patients with type 2 diabetes mellitus. Acta Diabetol 35:85-90

42. Mohan S, Baylink DJ (1995) Development of a simple valid method for the complete removal of insulin-like growth factor (IGF)-binding proteins from IGFs in human serum and other biological fluids: comparison with acid-ethanol treatment and $\mathrm{C}_{18}$ Sep-Pak separation. J Clin Endocrinol Metab 80:637-647

43. D'Ercole AJ, Underwood LE, Van Wyk JJ, Decedue CJ, Foushee DB (1976) Specificity, topography and ontogeny of the somatomedin $\mathrm{C}$ receptor in mammalian tissue. In: Pecile A, Muller R (eds) Growth hormone and related peptides. Excerpta Medica, Amsterdam, pp 190-205

44. Furlanetto RW, Underwood LE, Van Wyk JJ, D'Ercole AJ (1977) Estimation of somatomedin-C levels in normal individuals and patients with pituitary disease by immunoassay. $\mathrm{J}$ Clin Invest 60:648-657

45. Laemmli UK (1970) Cleavage of structural protein during the assembly of the head of bacteriophage T4. Nature 227:680-685

46. Hossenlopp P, Seurin D, Segovia-Quinson B, Hardouin S, Binoux M (1986) Analysis of serum insulin-like growth factor binding proteins using Western blotting: use of the method for titration of the binding proteins and competitive binding studies. Ann Biochem 154:138-143

47. Mohan S, Farley JR, Baylink DJ (1995) Age-related changes in IGFBP-4 and IGFBP-5 levels in human serum and bone: implications for bone loss with aging. Progr Growth Factor Res 6:465-473

48. Torring O, Firek AF, Heath H 3rd, Conover CA (1991) Parathyroid hormone and parathyroid hormone-related peptide stimulate insulin-like growth factor-binding protein secretion by rat osteoblast-like cells through an adenosine 3', 5'-monophosphate-dependent mechanism. Endocrinology 128:1006-1014

49. Malpe R, Baylink DJ, Linkhard TA, Wergedal JE, Mohan S (1997) Insulin-like growth factor (IGF)-I, -II, IGF binding proteins (IGFBP)-3, -4, and -5 levels in the conditioned media of normal human bone cells are skeletal site-dependent. J Bone Miner Res 12:423-430

50. Birnbaum RS, Bowsher RR, Wiren KM (1995) Changes in IGF-I and -II expression and secretion during the proliferation and differentiation of normal rat osteoblasts. J Endocrinol 144:251-259

51. Parker A, Rees C, Clarke J, Busby WS Jr, Clemmons DR (1998) Binding of insulin-like growth factor (IGF)-binding protein-5 to smooth-muscle cell extracellular matrix is a major determinant of the cellular response to IGF-I. Mol Biol Cell 9:2383-2392 